\title{
The Role of Martabat Tujuh within the Society of the Sultanate Buton Wolio
}

\author{
La Nalefo ${ }^{1}$ \\ ${ }^{1}$ Department of Agriculture Economic, Faculty of Agriculture, Universitas Halu Oleo, Kendari, Indonesia \\ Correspondent: La Nalefo, Department of Agriculture Economic, Faculty of Agriculture, Universitas Halu Oleo, \\ Kendari, Indonesia. E-mail: nalefounhalu@gmail.com
}

Received: August 8, 2017

Accepted: August 30, 2016

Online Published: October 16, 2017

doi:10.5539/ach.v10n1p6

URL: http://dx.doi.org/10.5539/ach.v10n1p6

\begin{abstract}
Martabat Tujuh laws that guided the State's administration on the sultanate of Buton were born because of (1) the existence of tyranny in society by the noble families, (2) the sultanate of Buton has no state constitution as a guideline for administering the government, and (3) the existence of people's hope with sultan to restore the economic crisis caused by the drought during that time.

Martabat Tujuh laws in political life, society and religion contain the virtues of value, namely (1) ainda indamo arataa sumanomo karo implies that someone should prioritize the safety of self and family; (2) ainda indamo karo sumanomo lipu, implies that the interest of the state is more important than the personal interest, (3) ainda indamo lipu sumanomo sarah implies that the interest of the leader is more important than the interest of the state, (4) ainda indamo sarah sumanomo religion, implies that religion is more important than the government. In addition, it also gives direction to the people to feel the pain between each other (binci-binci kuli), love each other (pomama siaka), keep each other (popia piara), listen the truth (poangka angkataka), and give each other in deficiency (poma maeka).
\end{abstract}

Keywords: The Sultanate of Buton and Martabat Tujuh

\section{Preliminary}

Martabat Tujuh Law is a guideline in the reign of Buton sultanate since 1613, and the guidelines for parabela in practice of customs. The law has very good democratic values, beyond current democracy.

The discourse of the establishment of Buton Raya province initiated by Buton youth figures, among others proposed that this province is in the form of Special Region because in Buton's history was never colonized by the Dutch and Japan. The Dutch entered Buton around 1611 in the framework of trade and education cooperation. Trade cooperation among others, is that all the spices in Buton are purchased by VOC at an agreed price and the price is adjusted to market price. Similarly, the cooperation in education such as the boys in Buton went to school in the Netherlands.

The discourse of martabat tujuh law which the parabela wants to revive, because the values it contains are still very relevant today. In the course of Buton's history, this law has up and down, especially in connection with the Dutch East Indies government.

Buton merged within the government of the Republic of Indonesia around 1960 or 15 years after Indonesia became independent. They merge with Indonesia voluntarily along with several kingdoms in Eastern Indonesia. Because it has merged within the Unitary State of the Republic of Indonesia, the Law used is 1945 Constitution, so martabat tujuh law is naturally lost dejure but defacto is still used by parabela in regulating indigenous people in Buton.

\section{Research Method}

\subsection{Research Location}

The determination of the research location was done purposively in Buton Sultanate, Bau-bau and Kampung Simalui Jaya in Sampolawa as Parabela Simalui Jaya territory which was in accordance with the purpose of the research, so that the data and information about the community of martabat tujuh. Location selection is based on some of the data obtained at the time of the author's dissertation. 


\subsection{Data Source}

The data obtained from this study comes from primary data and secondary data. Primary data were obtained from interviews and direct observation from researcher in the field on informants, namely: farmers, village heads, religious leaders, community leaders, humanist, lecturers, non-governmental organizations-NGOs, government and other stakeholders. Secondary data is sourced from Wolia Sultanate through Secretary La Ode Zaali and Sultan Wolio $40 \mathrm{La}$ Ode Muh. Izat Manarfah. Qualitative data collection is done through the determination of informants based on preliminary information about Martabat Tujuh.

\subsection{Data Collection Procedure}

In this study, certain effective data were collected and integrated in the analysis process, and presented in such a way to support the main theme of the research focus, thus constituting a separate construction as a product of interaction between field informants and researchers. The data collection techniques used, that is:

\subsubsection{Depth Interview}

In-depth interview (Esterberg, 2002) was conducted through meetings with informants in which questions and answers were held and discussions involved in various aspects of the issues sought in the study. In the process, in addition to informants explaining information about himself, his business activities, family life, or his life view, is also guided to explain things outside himself, such as community conditions, production relationships in working groups as well as social relationships in the society, especially on social institutional emphasis both which are cultural or structural / organizational. Life-story use is practiced for some key informants.

\subsubsection{Observation}

Observation was conducted in two ways, namely, regular observation and participation. The data collected through ordinary observation is the data observed by the researcher without requiring direct involvement. Full observation participation was conducted to obtain data requiring the involvement of researchers in the setting studied, such as behavior and activities of informants, local institutions and matters related to the substance of the problem in research. Marshal (1995) through observation, researcher learn about the behavior, and the meaning of it. Susan Stainback (1988) states, participant observation, researchers observe what people do, listen to what they say, and participate in their activities.

\subsubsection{Group Discussion}

Group discussions were conducted with focus group discussions (FGD) of experts through word cafe format. Implementation through word cafe format is done on the consideration that in this study consists of five materials that will be the discussion of each group, namely social, economic, ecological, cultural and institutional. Each group can be guided by three people with different tasks, namely one single guide, while others as host, recorder and review every point of problem and solution offered in the discussion.

Each of these materials can be discussed on each table within 30 minutes. After each discussion of each material on each table, declared completed by a single guide, the participants will move on different tables to discuss other materials and the movement of each person is random or unstructured.

\subsubsection{Document Study}

Document study conducted by researcher with reviewing a number of written sources both related to the subject matter and the location under review, to obtain data both primary and secondary.

\subsection{Data Validation}

Quality assessment of qualitative research result is done by setting criteria appropriate to the research standard (Salman, 2016). This context contains four criteria of data assessment in qualitative research used in this study, namely credibility, transferability, dependability, and confirmability. These four criteria are outlined as follows

\subsubsection{The Credibility of Data}

In this research, internal validation is done by matching the research findings with the interviews with the informants in three stages of research activity, as follows: (1) long time togetherness investment in the research location, make a persistent observation of crucial facts, the use of triangulation, and elaboration of theories for the interpretation of phenomenon that occurred during the study, (2) facilitate peer debriefing of community leaders or scientists who know the area directly, so that it helps the researcher remain 'objective' and discuss the 'authentic' assumptions that emerged during the study, (3) confirm the participant toward the data, categories, interpretations and conclusions tested together with the informant who involved since the beginning of this research is implemented. 


\subsubsection{Transferability}

Describe in detail and deeply about the background of socio-cultural life of community, through analysis and provision of sufficient information so as to reflect the characteristics of the communities studied.

\subsubsection{Dependability}

Involving auditors in conducting examination of the existence of topic studied at selected locations as well as checking the data and information collected by the researcher while maintaining the consistency of the research results with the conclusions formulated.

\subsubsection{Confirmability}

Done through the reflection of critical thinking of the researcher by elaborating the basic assumptions of economic sociology in the perspective of social network during the study of the phenomenon, with the aim of achieving trust of the research. This data confirmation activity is done from the beginning of data retrieval until the writing process takes place.

\subsection{Data Analysis Techniques}

The main analysis used in this research is analytical qualitative data analysis through interpretation and understanding. In order to obtain accurate data, field notes are refined and coded data and problems. Coding of data based on the results of criticism made, the appropriate data separated by certain code. The data obtained were analyzed comparatively through three stages:

The first stage is the process of crude data reduction of field notes. In the process, selected data are relevant to the research focus. Data reduction is done by creating data summaries, searching the themes, and creating a basic framework of data presentation.

The second stage is the presentation of data, namely the preparation of a collection of information into a statement to further withdrawal of conclusions. The data are presented in the form of narrative texts, initially scattered and separated on various sources of information, then classified according to theme and analysis needs. It is at this stage that the data is presented in a unified theme of the general state of community, a description of the community's activities around the sultanate of Buton, the dynamics of the phenomenon of conflict between people, the description of what is still preserved as a tradition in the management of forest resources, and an in-depth picture of the role local institutions in dealing with or as mediation of conflict resolution.

Third stage, drawing conclusions based on reduction and presentation of data. The conclusion draws gradually from the general conclusion at the time of data reduction then becomes more specific at the actual conclusion step. This series of processes demonstrates that the qualitative data analysis in this study combines the data reduction, data presentation, conclusion and cyclical conclusion.

Analysis of qualitative data using inductive method. This study does not test the hypothesis, but rather the preparation of abstractions based on the parts that have been collected and grouped. All available data is reviewed, reduced and then abstracted to form an information unit. Unit information interpreted and processed into conclusion. Withdrawal of substantive theory is done by making a comprehensive and holistic analysis of the elements that became the central problem in research.

\section{Result and Discussion}

Dayanu Iksanuddin comes from Buton and as the chosen human being. Man as the creation of Allah SWT, human events is the best incident consisting of two elements, namely physical and spiritual. The beauty of man in the outward form has not kept the stage of perfection and true beauty without being followed by spiritual beauty. According to Haron Din (2010, p. 17-30), human beings are special beings of God who are conferred special traits. Most experts place humans as the most important element ensuring the survival of a civilization (Norazlan Hadi Yaacob \& Aiza Maslan 2014, p. 83-97). The study of the rise of human civilization has been carried out by several study leaders from east and west with various approaches. The results of the study and the approach allowed them to produce works, including the birth of the law Martabat Tujuh caused by several factors, among others, (1) members of community, including the children of the nobility (kaomu) often act outside the corridor of the law, and cause state security conditions are not conducive. The family is essentially a container forming the character of each member, especially children who are still in the guidance and responsibilities of their parents. How a family treats its children will have an impact on the development of children's behavior, such as the different perception of their children's charachteristics set the stage for different behaviors toward boys and girls (Light, et al., 1989). The opinion also supports the lckona statement that the family is the first school of character formation of children (Dimerman, 2009), (2) the absence of a written constitution (positive law) which explicitly determines the 
authority of state administration that is needed by an independent and sovereign state, (3) the people of Buton just came out of economic crisis, namely hunger disaster caused by long drought in the era of third Sultan, La Sangaji. As Dukheim puts it, when society experiences suffering, it is necessary to find someone who can be held responsible for the suffering (Lukas, 1972).

These three factors trigger or encourage Sultan Dayanu Ikhsanuddin think wisely to make laws that will be enacted in the government of the kingdom of Buton. The person who is very meritorious in the drafting of this law is a "syekh shaykh Syarif Muhammad", Arab nationality. He is happy to assist Sultan in completing this law. Since the formation of martabat tujuh conditions of Buton society are controlled, the security of the state is conducive without any arbitrariness of society or government. The people's economy is improving (Dick, H.W 1975, p. 69-107).

The privileges of Martabat Tujuh laws and become parabela references (La Nalefo, 2013) as follows. First, as basis of science and source of law in constitution that takes the wisdom of Qur'an and hadith united in unity of system, that is the system of government, nation and state. The role of religion in establishing a civilization is another agenda in the study of human civilization (Norazlan Hadi Yaacob \& Aiza Maslan 2014, p. 83-97). The values of Martabat Tujuh are universal, in other words the value contained is applied anytime and anywhere. If seen from Buton geographical of various tribes and languages in the Sultanate of Buton, it can be said the archipelago is small. Although the people are very plural and have diverse languages, the values of martabat tujuh can unite them in unity of the Sultanate of Buton. The universal value can be seen in "binci-binci kuli" that is the taste value gradually like pinching the skin, pinching yourself before pinching another person, in the value means having a high empathy.

The taste of value can unite the State of Buton Sultanate. Binci-binci kuli in daily life are manifested in mutual compassion (poma-masiaka), mutual respect for each other (pongka-angka taka), mutual care (popia-piara), and obedience (poma maeka). Obeying is not due to the position of a person so that he must be obeyed, but because every human being has right. This right shall not be violated by any person (article 1 of Martabat Tujuh laws). These four basic values are applied by people of Buton in life of society, nation and state and applied well by parabela from the past until today. The application of the values of Martabat Tujuh creates a noble character and does not offend the feeling of others. With the creation of a noble character then each person or household in society will work according to the rules desired by all parties. Thus harmony, peace and well-being will be realized. This is in accordance with Ali Syariati (1979) that the view of tauhid and role in development of society and civilization. He concluded that the development of society and civilization demands absorption of the concept of tauhid into every activity and daily life of Islamic society. According to Abdul Azis (1983) Ali Syariati stresses that tauhid is the life principle of individual and Muslim society. Cruelty, fear and greed bring about the destruction and collapse of human morals. On the contrary, tauhid gives people freedom and salvation.

Second, martabat tujuh laws are excavated from the science of tasawuf especially mysticism (Eymal, et al, 2016, p. 136-146). Dayanu Ikhsanuddin adopted martabat tujuh of Ibnu Arabi and was extracted from twenty character of Allah SWT through the path of ijtihad so as to survive in all ages. The value contained in martabat tujuh is humanizing human beings become khalifatullah which spiritual prosperity. Therefore, people obey the government through customary law. Someone who is uncivilized, obviously the person does not live up to his aggression. So that in the era people will feel ashamed if he is said not to be well-mannered, and better die if it is said so.

Third, the values of martabat tujuh are horizontal and vertical. Martabat tujuh guarantees and regulates people's lives not only the world life, but also the life hereafter. The values are (1) deep religious values, (2) high human values, (3) solid social values, (4) the value of strong unity, (5) high nationality values, and (6) the value of transparent honesty. These values can always guarantee the tranquility of Buton people from time to time. These three factors are in line with the thought of Ibnu Kaldum (Wan Hashim wan the, 1977) a great thinker who studies scientifically and comparison of human civilization is social beings. As human being of the necessities is to cooperate and help each other. The principle to human progress is asabiyah, the spirit of us and cooperation. With its form asabiyah, humans are capable of realizing the kingdom, developing economics, art, science and technology that bring progress in life.

\subsection{The Value of Martabat Tujuh in Political Life}

There is no joint life, knowledge and human civilization that is not touched by the passion of political life. Politic is used for a variety of meanings and interests. Politic means a set of hypotheses about process or government institution, or it can also refer to the principles and norms that control political behavior. Aristotle agrees with Plato that man is a political animal that can fulfill his character only in policy, that the state is moral institution that exists 
to help man achieve his perfection, which the true state seeks to create prosperity for all and not for the good of several groups (Schman 2002, p. 126-133).

Aristotle explains the essence of social life is political activity and interaction with one another from two or more people will definitely involve political life (Roode, 1995). From the theory can be concluded that the political process is influenced by norms or values owned by the community. The state makes political interaction with others in an institutional framework (government). When humans want to determine their position in society and to realize a common desire, they will seek to influence others to accept their views and call it political activity. In order to achieve mutual desire, they engage in political interaction with other people or groups, or state institutions. Interaction and deliberation with other institutionalized person will result in a shared distribution of decisions.

The politic in the Sultanate of Buton is well applied by the parabela called Gau or deliberation. The commencement of all the rules of the land comes from past agreements, decisions on the state or the outcome of political process in the sultanate of Buton are well achieved through a discussion process. Martabat tujuh values associated with politics are the values of society's service to the state, namely:

- Ainda-indamo arataa sumanomo karo, implies that self-interest and family or people are very important than property, is a manifestation of the devotion and sacrifice of the people towards fellow citizens and mankind. Property that is valued at any price is willing to be sacrificed for the sake of self or people's safety. What is the property whether self or other people do not feel safe and comfortable, the property has no value, it will cause the jealousy of other people that will cause unity to be loose. If this estrangement occurs then the unity that becomes the common goal (state) to realize a prosperous life will not be achieved. For the sake of self-interest and family or crowd, then property is not everything. In Simalui Jaya and Lapandewa Tambunaloko, ainda-indamo arataa sumanomo karo was manifested in the form of donations of overseas citizens to build the village. The manifestation that they are an inseparable part of their homeland.

- Ainda-indamo karo sumanomo lipu, implies that the interests of the state are important more than personal interests. Karo is personal and family, individual or people who must be protected by the state or government. However, to defend a higher interest that is lipu or karo state or citizens willing to sacrifice for the country. To sacrifice themselves in the sense that they are willing to sacrifice for the sake of defending and maintaining the lipu even if their lives. This value is a form of community service for the common interest of the Buton sultanate. In parabela area of Simalui Jaya and Lapandewa, the form of ainda-indamo karo sumanomo lipu is that although the citizens live happy in another country, they always build permanent house in hometown.

- Ainda-indamo lipu sumanomo sarah, implies that the government's interests are more important than the state. Sarah or state organizer based on discussion is the common property of all people and government. The State shall be nurtured and retained wholly from threatening dangers. However, if higher and more salient interests require the safety of the government (sarah) certain parts of the country in a compulsion may be sacrificed. The form of ainda-indamo lipu sumanomo sarah is when planting arrived, then the first priority to help planting land belonging to parabela. Similarly, if there is a parabela job, such as repairing his house, then without being called all the citizens who are in the village helped without burdening parabela.

- Ainda-indamo sarah sumano agama, implies that religion is more important than the government. That is, if a person or several people of the Sultanate (sarah) violate state regulations or applicable law, the apparatus concerned must be removed from his position for the integrity of religion which occupies the highest level in the philosophy of Buton. Or with another meaning, sarah is said to be more important than the state. But if the critical situation in which Sarah's salvation is truly threatened, two alternatives must be drawn: (1) the government surrenders as long as the religion survives, (2) the government plunges into the battlefield with the conviction that they are fighting and dying in a way that good to defend the truth. One of the forms of ainda-indamo sarah sumanomo agama after each prayer is always followed by a discussion about what should be done for the progress and welfare of citizens.

The red threads of the above values are (1) the property (arataa), (2) the human self itself (karo), the whole state (lipu), the religious device based on discussion (sarah), (5) religion or belief and official beliefs held by the state.

The four values associated with the country, ainda-indamo lipu sumanomo sarah, are directly related to the outside world. This value gives space to the ruler to run his politics for the welfare of the citizens. As has been explained that the political decision (gau) in the state of the Sultanate of Buton is processed through consensus made through the institution of sarah or governmental apparatus. Government policy is one of political activity, in which the political activity of a person or group is to achieve a common goal through political interaction with others in an institutional framework. 


\subsection{The Influence of Martabat Tujuh Values on Dutch Colonial Period}

The Netherlands entered the state of the sultanate of Buton in 1613. At this time, the state of the Sultanate of Buton is not one of the Dutch colonies. In other words, Buton was never colonized by any country. In Dutch colonial era, the life of society and government went according to the existing constitutional rules. The arrival of the Dutch was well received by Sultan Buton. On January 5, 1613 an agreement was reached between the Dutch and Buton Sultanate to conduct into bilateral cooperation agreements. This agreement is known as baane agreement or first agreement. The contents of agreement include the cooperation of defense and security of domestic and foreign, trade, and cooperation in the field of development. On the agreement, the Dutch were represented by comandeur Appolonius Schot. Buton is represented by Sultan Dayanu Iksanuddin. The agreement between two parties does not interfere with or affect the life of community either in legal, economic, political or educational fields.

The process of law enforcement proceeds in accordance with the code of law applicable in the Sultanate of Buton. In the field of community welfare (economy, agriculture and trade) continue to use populist economy. In the field of education in 1909, the children's son school opened in Bau-bau, and in 1938 the VOC's school was opened (Sultra Document, 1977). Educational system adapted to the values of Martabat Tujuh. Religious education and state defense are still implemented through the teachings of Sufism. Religious teaching was not affected by the arrival of Dutch colonialism. Institutions of religious still exist in giving spiritual splashes in society.

In political sphere, the government was running as usual, so that no Buton people became colonial Dutch henchmen or as landlord who seized and oppressed his neighbors even though in fact the lands in Buton could not be controlled by anyone because all the land under power of parabela by approval the empire.

In 1636, Governor-General Van Diemen traveled to Buton and was the second person. In the government of La Buke, Buton relationship with the Dutch colonial began tenuous caused by Buton army participated in the movement kakiali in 1634, namely the occurrence of resistance wawani hitu assisted by Makassar attacked the Netherlands. In the attack, Buton sent 30 troops and with that incident the friendship became broken.

On 25 June 1667, the 10th sultan of Buton La Simbata reentered into a bilateral agreement with the Dutch colonial represented by Spelman. The contents of this second agreement, the Dutch began to show his power. The Dutch began to intervene in the government policy of the Buton sultanate. One of the contents of the agreement "if there is a change of the sultan of Buton, should be the known by the Dutch colonial and the sultanate of Ternate." Still in the same agreement Binongko area submitted to the Dutch colonial and told the community to cut all the clove trees in Wakatobi. Although the agreement of the 10th sultan with the Dutch colonial was agreed, but in the reign of La Tangkaraja the treaty was ignored, which at the elevation of the 11th sultan La Tangkaraja did not inform the Dutch and Ternate. The election was done in accordance with the existing constitution, La Ode Izat Manarfah narrates.

The 23rd sultan of La Karambau in the Buton Sultanate openly opposed the contents of Spelman's agreement. This was done because the Dutch was no longer in accordance with the norms that existed in the sultanate of Buton and the Spelman treaty was considered a form of contempt for the sultanate of Buton.

The Dutch colonial influence during the sultanate until the reign of Sultanate ended can be denied by the values contained in martabat tujuh. The change of name kadie as the center of parabela power with the term Dutch colonial district in 1913, is not an urgent matter in the life of the state, so it can be concluded that there is a Dutch colonial period. The life of the State of the Sultanate of Buton does not occur the shift in the value of martabat tujuh and parabela life in regulating society in rural/kadie, as shown in the following table.

Table 1. The Values of Martabat Tujuh on Dutch Colonial Period in Buton

\begin{tabular}{|c|c|c|c|c|}
\hline \multirow{2}{*}{$\begin{array}{l}\text { The values of martabat tujuh as one of value holding by parabela in running the } \\
\text { government }\end{array}$} & \multicolumn{4}{|c|}{ Areas of life } \\
\hline & A & $\mathrm{B}$ & $\mathrm{C}$ & $\mathrm{D}$ \\
\hline 1. Binci-binci kuli & + & + & + & + \\
\hline 2. Pomama siaka & + & + & + & + \\
\hline 3. Popia piara & + & + & + & + \\
\hline 4. Poangka angkataka & + & + & + & + \\
\hline 5. Pomae maeka & + & + & + & + \\
\hline 6. Ainda indamo arata sumanomo karo & + & + & + & + \\
\hline 7. Ainda indamo karo sumanomo lipu & + & + & + & + \\
\hline 8. Ainda indamo lipu sumanomo sarah & + & + & + & + \\
\hline 9. Ainda indamo sarah sumanomo agama & + & + & + & + \\
\hline
\end{tabular}

Source: La Ode Muhammad Izat Manarfah (The Buton Sultanate 40th), 2017

Information: $\mathrm{A}=$ Law; $\mathrm{B}=$ Prosperity $\mathrm{C}=$ Education; $\mathrm{D}=$ Politic 
The table illustrated that the sultanate of Buton was not affected by the Dutch colonial presence on all aspects of life, although at that time some sultans had entered into agreements and cooperation with the Dutch colonial. One of the treaties that disadvantaged the Buton community was an agreement between the sultan of La Simbata and Spelman, but the implementation of the treaty was ignored by Butonians and the sultans thereafter. As mentioned by some cultural figures, religious figures and community leaders such as Abu Bakr, La Taura, La Toa said that the Dutch colonial influence on the sultanate did not significantly replace or eliminate the values of martabat tujuh.

\subsection{The Existence of Parabela Institution}

The old order period occur from 1945-1966. In Buton's political history, the old order period was divided into two periods. The first period was 1945-1955, and the second period was 1955-1966. The first period of the sultanate of Buton has merged within the framework of the unity of the Republic of Indonesia. Nevertheless the reign of the Buton sultanate remained until 1960, where the parabela followed all the orders and behavior of the empire. In 1950 the system of imperial democratic government was replaced by the Swapraja (document of DPRD Sultra, 1977) even though the government had entered the swapraja system, the Sultan remained the head of government, and customary law applicable. In the era of swapraja-government there was a slight shift in the governance structure in which the institution of legal facilities of the Great Mosque of Kraton Buton was not included in the structure of swapraja-government. Religious facilities / legal stand alone outside the law of government.

The influence of martabat tujuh in both periods (old and new), old order period is still strong. This can be seen the strongness of Sufism adopted by most of the people of Buton, although at this time has entered new teachings or the birth of a new civilization, but can not melt the belief of the people of Buton towards the values of martabat tujuh.

The influence of martabat tujuh as the law of the sultanate of Buton by material and formal law was still strong in the first period (1945-1955). In this period, it still apply the laws and rules of state administration as regulated in the law of the Sultanate of Buton, although Buton has become part of the Republic of Indonesia United incorporated in the confederation of the State of East Indonesia based in Makassar.

The influence of martabat tujuh in the political field can be seen in Malino Conference 1955 discussed the changes of the Confederation of the State of East Indonesia going back to the Unitary State of the Republic of Indonesia. At this conference all the confederate members of the kingdom agreed to merge into the Unitary State of the Republic of Indonesia by signature. Unless the sultan of Buton in the conference was not signed, this was because there was no consent of the Council of Sio Limbona, so the sultan Buton did not dare to sign. This incident is one of indicator that the reign of the Buton Sultanate still firmly defends and implements the norms contained in martabat tujuh law.

After the Malino conference, the influence of martabat tujuh began to weaken in the body of government institutions because the State of the Buton Sultanate integrated into the Unitary State of the Republic of Indonesia in 1960. The Law of martabat tujuh replaced with the Basic Law of 1945. It should also be explained that in the life of Buton people even though the state constitution has change but the values contained in martabat tujuh remain alive in the hearts of the people and run entirely by parabela.

Table 2. The influence of martabat tujuh values in old period

\begin{tabular}{llcccc}
\hline \multicolumn{2}{l}{ The values of martabat tujuh } & \multicolumn{3}{c}{ Areas of life } \\
\cline { 2 - 5 } & & $\mathrm{A}$ & $\mathrm{B}$ & $\mathrm{C}$ & $\mathrm{D}$ \\
\hline 1. Binci-binci kuli & $+/+$ & $+/+$ & $+/+$ & $+/-$ \\
2. Pomama siaka & $+/-$ & $+/+$ & $+/+$ & $+/-$ \\
3. Popia piara & $+/-$ & $+/-$ & $+/+$ & $+/-$ \\
4. Poangka angkataka & $+/-$ & $+/+$ & $+/+$ & $+/-$ \\
5. Pomae maeka & $+/+$ & $+/-$ & $+/+$ & $+/-$ \\
6. Ainda indamo arata sumanomo karo & $+/-$ & $+/+$ & $+/+$ & $+/+$ \\
7. Ainda indamo karo sumanomo lipu & $+/-$ & $+/-$ & $+/+$ & $+/+$ \\
8. Ainda indamo lipu sumanomo sarah & & $+/-$ & $+/-$ & $+/-$ & $+/-$ \\
9. Ainda indamo sarah sumanomo agama & & $+/+$ & $+/-$ & $+/+$ & $+/+$ \\
\hline
\end{tabular}

Source: La Ode Muhammad Izat Manarfah (Buton Sultanate 40th), 2017

Information: $\mathrm{A}=$ Law $\mathrm{B}=$ Prosperity $\mathrm{C}=$ Education; $\mathrm{D}=$ Politic

The value is used as a code of ethics in society and state. In this period, the influence of the value of martabat tujuh in depth can be seen in the field of socio-cultural and education. The values of martabat tujuh are still 
preserved in the socio-cultural implementation of the people of Buton. In education area shows binci-binci kuli (tolerance), poangka angkataa between students and teachers, teachers and students, teachers and boss and fellow members of the community with the state. In the same field to improve the nation's intelligence, precisely in 1946 has been built MULO and 1950 laying the first stone of SKP negeri Bau-bau. However, some people who no longer believe and are indifferent to martabat tujuh.

From table 2 show the influence of martabat tujuh that still stands out is the tolerance/binci-binci kuli, pomae maeka, and ainda indamo sarah sumanomo agama, that at this time the law enforcement still highlight the value of tolerance, law-abiding, uphold justice, and the more important is to decide things with religious principles that are still held. At the parabela level an official decision shall be made by deliberation at the baruga. Anyone who acts should not do as he wishes and whoever he is when breaking the law will be subject to sanctions.

In welfare area (economy) included in it and the main is agriculture on first period still highlight all the values of martabat tujuh. In the second period, the prominent values were binci-binci kuli, poangka angkataka, ainda indamo arataa sumanomo karo. Increasing prosperity, the economic system uses people as the basis same with economic system in the sultanate where the system is supported by the culture of mutual assistance that is inherent in Buton society, especially in parabela indigenous people.

In the field of social culture, especially education, both in the first period and in the second period in the community still highlight the overall value of martabat tujuh, especially the relationship between society and the government.

The political field of the first period still highlighted the overall values of martabat tujuh, but in the second period the prominent values were pomae maeka (mutually obeying each other), ainda indamo karo sumanomo lipu (the interest of the state more than the personal interest), ainda indamo lipu sumanomo sarah (the interests of government "enforce legislation" is more important than the interests of the state or the people), and ainda indamo sarah sumanomo agama that means religious interests above all things. At this time also a prominent value is ainda indamo arataa sumano karo, and ainda indamo karo sumanomo lipu which has the relevance of mutual assistance system, and ainda indamo sarah sumanomo agama has relevance to the religious socialist principle in the old order period.

\subsection{The New Order Period and Reformation}

The new order period in Indonesia took place during 1966-1998 which was marked by the decline of Soeharto from the top of leadership. The new order is characterized by secularistic-materialistic tendency. Buton society life in general is not affected by the new order system, they are a syufistik society. The influence of martabat tujuh at this time is still strong, most of the people of Buton still hold on Sufism. In most kadie who led by parabela customarily, such as Simalui Jaya, Lapandewa and Rongi still believe in Sufism run by religious medium as a legal medium (sarana hukumu).

The values in martabat tujuh especially ideology, social and culture can create peace in the society. It uses the pattern of approach by parabela. Ethics of the state of the New Order era is very weak, such as recruitment of leaders and government officials in the election process and the appointment of office no longer see the expertise of a person, character and behavior, provided nominated by any political party can be a leader regardless of experience, behavior and morality of the candidates. However, in the implementation of the state, the value of discussion and mutual respect still preserved, the policy decision taken still uses the system of deliberation and still occupies the oldest as a role model. In the new order era occur legal emphases that were imposed on the people, especially indigenous people.

The period of reform until now marked by the emergence of changes in all aspects of the joint life of nation, state, and society has caused turmoil from all the joints of life of Indonesian society, not least in Buton. Parabela in relation to political life can not influence society to follow a particular political stream nor can it be influenced by anyone in determining its political choice. At this time the public awareness of the morals of state organizers is increasing, wanting to create justice, enforcing the law supremacy in all spheres of life. The society demand in realizing the values of martabat tujuh who want the state organizer free from the practice of collusion, corruption and nepotism. The demands of society should not be done in anarchic and arrogant ways, but must be carried out properly, and prefer the morality approach. They hope that those who lead must be role models because there is a belief that role models have the highest value in society.

At the time of reform the tendency of Buton society to the values of martabat tujuh strengthened in all fields. The majority of Buton people, especially kadie communities in remote villages, still hold the values of martabat tujuh, 
even though rationalization is developed by educated young generation and many follow a modern religious stream that is less amenable to spiritual activity.

The weakening of the value of martabat tujuh in some aspects of life during the New Order era caused by several factors, including:

1) In new order era, Buton was branded as the main base of the Communist Party of Indonesia (PKI) which resulted the regent Muhammad Kasim, the son of Buton imprisoned and hanging without proper judiciary. Similarly, the fate of some government officials and some people jailed for decades without going through a fair trial process. They were tortured, branded as PKI, murdered, deprived of their humanitarian rights, and forced to work by despotic rulers who were very cruel than romusa in Japanese era. This resulted in trauma among Buton people. Anyone who still retains the values of martabat tujuh will be claimed by the ruler as PKI. As a result, there was a prolonged trauma among religious leaders, cultural figures, community leaders, then occurr a stagnation that paralyzed all aspects of culture, especially parabela activists in the Buton region.

2) There is an indication in the implementation of the wheels of government, the policy of the elite is decided not in accordance with the conditions of society or the interests of the people. Parabela in leading the people of Buton still keep up to the oath and the teachings of martabat tujuh. In every ceremony, the parabela swearing is always done to remind the values of the oath, and is the subject matter. Compare with the oath by state officials who make oaths only once in five years. Meanwhile, according to parabela oath will expire after the earth rotates for 365 days or a year. According to parabela, the oaths in the second year become expired, it has undergone a process of disconnection with the creator. For a year the sun has returned to its axis, therefore the annual oath and event must be carried out, not only for the customary ceremony itself, but all the citizens must be reappointed for themselves, families and citizens who believe in parabela.

During the reform era there was a new tendency among the young Buton intellectuals to actualize and refine the values of martabat tujuh into the system of government especially with regard to state officials in particular relating to law supremacy, the welfare of the people, social justice and other matters relating to the interests of society and country. This movement was pioneered by young figures such as Abdul Zainuddin Napa, et al since 1986. Abdul Zainuddin Napa comes from the Cia-cia Kancinaa Tanamaeta, Wajo Market District. He is the originator and activator of the establishment of Buton Raya Province based on the concept of martabat tujuh Law. The discussions have been taking place since 1985 when we were both studying at Universitas Halu Oleo and active in HMI Kendari. The discussions about the values contained in martabat tujuh as the Buton's constitution, and martabat tujuh law are older than the American constitution of 1776.

The struggle to establish Buton Raya province started with the establishment of several districts in the former Buton sultanate region (1) Wakatobi District, (2) Bau-bau city, (3) Bombana District - although in its development they did not want to join Buton Raya Province, 4) North Buton regency - expantion from Muna District, included in Buton Island - (5) Middle Buton Regency, (6) South Buton Regency. Thus administratively has been eligible for the establishment of a province at least five districts. This struggle is a picture that the values of martabat tujuh as a parabela working guidelines still get high sympathy among scholar.

Table 3. The influences of martabat tujuh values in new order era until reform order in Buton, especially when mostly of the local men's officials were became suspect of PKI

\begin{tabular}{|c|c|c|c|c|}
\hline \multirow[t]{2}{*}{ The values of martabat tujuh } & \multicolumn{4}{|c|}{ Areas of life } \\
\hline & $\mathrm{A}$ & $\mathrm{B}$ & $\mathrm{C}$ & $\mathrm{D}$ \\
\hline Binci-binci kuli & - & + & + & - \\
\hline Pomama siaka & - & + & + & - \\
\hline Popia piara & - & - & + & - \\
\hline Poangka angkataka & - & - & + & - \\
\hline Pomae maeka & - & - & + & + \\
\hline Ainda indamo arata sumanomo karo & + & + & + & + \\
\hline Ainda indamo karo sumanomo lipu & - & + & + & + \\
\hline Ainda indamo lipu sumanomo sarah & + & - & + & - \\
\hline Ainda indamo sarah sumanomo agama & - & + & + & - \\
\hline
\end{tabular}

Source: Abdul Zainuddin Napa, SE 2017Information: A = Law; B = Prosperity; C = Education; D = Politic

The event that made the Butonese official as PKI, for the Buton people was an unforgettable tragedy throughout the ages. The rulers at that time arbitrarily exercised power without humankind, so the value of martabat tujuh that 
still stands out in the field of law, in the new order era ainda-indamo arataa sumanomo karo and ainda-indamo lipu sumanomo sarah. At this time justice can be traded by the rulers for Buton society.

In the field of welfare, the prominent values among others, pomama siaka, ainda indamo arata sumanomo karo, ainda indamo karo sumanomo lipu, religious values and binci-binci kuli only apply between communities, but do not apply to the government because the elites often participate in business world by using power in cooperating with businessmen of snapper fish. In the field of education, all the values contained in martabat tujuh are still touched by the high sense among peoples, providing good moral and ethical examples, a high sense of brotherhood through the teachings of loving homeland, and a sense of sacrifice for the sake of the nation and state. Nevertheless, the role of the state in education has not given special attention, except by the community itself which facilitates itself to improve education.

In political field, in the New Order period there was a tolerance to love each other. The political elite trying to find ways how to gain power in various ways for the sake of the people so that the values of martabat tujuh that still stands out are pomae maeka which means mutual respect, ainda indamo arataa sumanomo karo means people, discussion, and ainda indamo karo sumanomo lipu, which means unity and national unity.

The value of martabat tujuh is defended by parabela. The values contained in martabat tujuh are the value of society, nation and state based on religious values. The values are universal, open and wherever applicable, the value binci binci kuli for example in the life of Buton people becomes the foundation of association even though they are plural society but remains united by the same feeling. The value of feeling (binci binci kuli) is universal because every human being still has a desire to be respected, loved, protected and obeyed (Maslow 1947, p. 370-394). Binci binci kuli in the application of community life are manifested through the respect of the fellow human beings, poangka angkataka and poma masiaka are manifested in mutual love for each other, popia piara is manifested in the form of mutual care and protection of each other and pomae maeka is manifested in the form of obedience one another.

As the wheel of life spins, changes from time to time, Buton not escape from the wheel of change, especially in the field of economic, technological and socio-cultural. Faced with these changes, martabat tujuh remains enforced by parabela. Binci binci kuli greatly dominate the life of Buton people. The value will still be sustainable throughout the ages.

Some of the factors why the values of martabat tujuh held by the people of that time and contemporary Butonese society, that are; first, the values contained therein really fit the needs and conditions of society at that time, ie the chaos that happened turned into peace, no more oppression by the ruler to the people.

Second, the establishment using spiritual methods, discipline, meditation or generating the power of contemplative mind and with this power the ability of people to reach the value of truth is intrinsically obtained by knowing the truth directly, then rationality applied by looking at the life and needs of society. From the results of the contemplation is then made in the form of martabat tujuh constitution, as well as in the form of parabela election. Thus, martabat tujuh is made not based on the rationality of passion or rationality of the ruler's preference, or individual preference. In other words, the making does not begin with the rationality that is still shrouded by lust and omission of truth, the constitution is not made on the basis of the interests of political parties. Thus are several factors why the values of martabat tujuh constitution are still firmly held by the contemporary Buton people.

In carrying out government activities, the Sultanate of Buton made martabat tujuh as a guide in implementing government policy. Government policies are issued on the basis of the values of martabat tujuh, as well as parabela's behavior of each kadie or village of parabela's power. In implementing these values is also supported by the understanding and practice of strong religion. A strong religious practice will create a moral person. All humans who profess the religion well will certainly know God perfectly.

If a man knows his Lord will be guaranteed in his daily life no one will do something bad to him and will know his neighbor or others as well as they know his Lord, said La Taura, parabela in Simalui Jaya. In addition to the values that unite the community, martabat tujuh laws as guidelines for the implementation of parabela activities, contains the values of citizenship of the nation (nation contains the meaning of territory and leadership), as follows:

1) Ainda-indamo arataa sumanomo karo, which means that self-interest and family, as well as the interests of the people above the interests of property. In this understanding every individual will be willing to sacrifice his property for the sake of the unity of the Buton family, or for the benefit of the community. The wandering Butoners are obliged to send money for development in their village, initiated by parabela as a trust center of the wander community in their hometown. 
2) Ainda-indamo karo sumanomo lipu, which means that the interests of homeland defeat self-interest and family. Buton people willing to defend the country even if the family became displaced.

3) Ainda-indamo lipu sumanomo sarah, which means that law enforcement and government above the public interest. The law in this case is sourced from martabat tujuh, hukumu agama and hukumu adjati adhered firmly by the people of Buton. Sarah as a vessel that runs the law well and fair, because society will defend them from all interests. If not done well, the community will sue against the law enforcement.

4) Ainda-indamo sarah sumanomo religion, which means that the interests of religion above the interests of homeland. Religion in the community of Buton occupies the highest position both in government and in everyday life. Traditional and religious events always live side by side, there is no conflict between the two.

The value of humanity is more important than property. The interests of the state are more important than personal or group interests. What is the meaning of homeland or state, if law and government are not enforced, and what does it all mean if the people are not religious. The highest value in martabat tujuh is the value of religion. Religious leaders according to parabela is in addition to worship, is also required to keep all of God's creation on earth, for example, preserving the forest, providing food for the animals that exist and roam around the village. Therefore, if pigs eat corn belonging to the community, they should not be angry and cursing.

The value of martabat tujuh is vertical and horizontal so it remains used as a view of life. In addition to these values are open and democratic, it also does not question the issue of different beliefs, as well as differences in skin color.

\section{Conclusion}

The birth of martabat tujuh laws is caused by (1) the noble families often acting arbitrarily to the local society, (2) there is no written constitution in the Buton Sultanate, (3) the economic crisis that hit the Buton people due to the long drought. Martabat Tujuh Law as the basis of science and the source of law in the Sultanate of Buton who took the wisdom of the Qur'an and hadith united in the system of government. Martabat tujuh values are very universal that can be seen in binci-binci kuli, pomama siaka, popia piara, poangka angataka, and pomae maeka.

The values contained in martabat tujuh are horizontal, ie regulate the relationship between humans and verticals that regulate the human relationship with God. In addition, there is a value of community service to the state, which can be seen in ainda-indamo arata sumanomo karo, namely self-respect and family rather than property, ainda indamo karo sumanomo lipu, namely the importance of the state interest than self and family, ainda indamo lipu sumanomo sarah, means the priority of leaders rather than the state, and ainda indamo saran sumanomi agama, namely the preference of religion rather than the leader.

\section{The List of Local Terms}

from Bahasa Wolio (BW), Cia-Cia (BC) Bahasa Buton (BB)

Ainda-indamo arataa sumanomo karo (BW): Kepentingan diri sendiri dan keluarga lebih utama dari pada harta. Arataa artinya harta. Karo = badan atau keluarga batin

Ainda-indamo karo sumanomo lipu (BW): Kepentingan negeri lebih utama dari pada kepentingan pribadi. Lipu= negeri.

Ainda-indamo lipu sumanomo sarah (BW): Kepentingan pemerintahan lebih utama dari pada negeri.

Ainda-indamo sarah sumanomo agama (BW): Agama lebih utama dari pada pemerintah.

Batata (BB/BC): Sumpah yang dibacakan oleh parabela atau Sultan pada saat dilantik.

Binci-binci kuli (BB): Cubit diri sendiri, apabila sakit maka sakit pula bila mencubit orang lain. Karena itu pada masyarakat Buton dilarang menyakiti orang lain.

Cia-cia (BC/BW): Salah satu sub etnis Buton yang memiliki ciri khas bahasa dan kebudayaan.

Gau (BB): Proses politik lokal. Gau-gau bisa berarti berbohong demi mendapatkan keuntungan, atau berupaya menyelamatkan diri dari kebohongan yang telah diketahui umum.

Kaombo (BB/BC/BW): Hutan lindung yang harus dilestarikan, karena menjadi sumber mata air.

Kadie (BW/BC): Pemerintahan setingkat desa di bawah kesultanan Wolio yang dipimpin oleh parabela.

Martabat Tujuh/MT (BC/BW): Undang-undang Negara Buton yang dibuat oleh Sultan La Elangi pada tahun 1613. Undang-Undang ini kemudian menjadi pegangan pemerintahan sesudahnya dan juga dijadikan pegangan bagi kepemimpinan parabela di wilayah Kadie. 
Parabela (BC/ BW): Orang dipilih oleh kilala untuk menjadi pemimpin budaya di wilayahnya. Parabela memiliki perangkat, yang dipilih oleh parabela. Parabela, bisa sebagai lembaga, juga bisa sebagai pemimpin. Sebagai lembaga maka seluruh keputusannya harus ditetapkan di Baruga (Galampa), dan sebagai pemimpin maka ia akan memimpin masyarakat dalam aktivitas sosial dan kemasyarakatan.

Penjaga Sangia (BB/BC): Perangkat parabela yang bertugas menjaga hutan, mata air termasuk menjaga pohon-pohon besar di hutan atau di sekitar kampung yang ada roh penunggunya.

Poala (BC): acara adat memperingati hari-hari tertentu kematian seseorang. Biasanya pada hari ke tiga, hari ke tujuh, hari ke empat puluh, dan hari ke seribu. Sebelum masuk pada hari ke tujuh biasanya dibacakan alquran sampai 30 juz.

Pomae-maeka (BW/BC): Saling menyayangi, untuk menciptakan kedamaian dalam masyarakat.

Popia-piara (BW/BC): Saling memelihara antara satu dengan yang lain dalam masyarakat, tidak memandang kedudukan atau status sosial.

Poangka-angkataka (BW/BC): Saling mengikuti, yakni mengikuti pada jalan yang benar, bukan jalan yang salah.

Pomae-maeka (BB): Saling mengingatkan agar dalam perjalanan kehidupan tidak terjerumus kejalan yang tidak benar.

Poangka angka taka (BB/BW): saling menghargai, saling mendukung satu sama lain. Suatu sikap di mana setiap orang harus melindungi yang lainya.

Sio Limbona(BW): Sara Kerajaan/Kesultanan Buton yang memilih Sultan dan perangkatnya. Semacam anggota DPR.

\section{References}

Azyumardi, A. (1999). Menuju Masyarakat Madani. Gagasan, Fakta dan Tantangan. PT. Remaja Rosdakarya, Bandung (in Indonesian).

Demmallino, E. B., Ali, M. S. S., Gassing, A. Q., Lampe, M., Nalefo, L., Busthanul, N., \& Ibrahim, T. (2016). Sufism and Behavior of Maritime Economic Community (Case Study on Pakkaja Community in South Sulawesi). Journal of Sustainable Development, 9(3), 136-146.

Dick, H. W. (1975). Perahu Shipping in Eastern Indonesia, Part I, Buletin of Indonesian Economic Studies II: 2 (pp. 69-107).

Dimerman, S. (2009). Character is the Key: How to Unlock the Best in our Children and ourselves. Mississauga, Canada: Jhon Willey \& Sons Canada.

Din, H. (2010). In Analysis of The Generalogy of Sulu. Journal Asian Studies, 46, 17-30.

Esterberg, K. G. (2002). Qualitative Methods in Social Research. Mc Graw Hill, New York.

Light, D., Keller, S. Jr., \& Calhoun. (1989). Sociology (5 $5^{\text {th }}$ ed.). New York: Alfred A.Knopf, Inc.

Lindeboom, J., Schmand, B., Tulner, L., Walstra, G., \& Jonker, C. (2002). Visual association test to detect early dementia of the Alzheimer type. Journal of Neurology, Neurosurgery \& Psychiatry, 73(2), 126-133.

Lukas, S. (1972). Emile Durkheim. His Life and Work. New York. Harper \& Row.

Marshall, C., \& Rossman, G. B. (1995). Designing qualitative research (2nd ed.). Sage publications.

Maslow, A. H. (1947). A Theory of Human Motivation. Journal of Psychology, 370-394.

Nalefo, L., Kamarulzaman Yusof, M., Saleh, S. A., Salman, D., Demallinno, E. B., Santi, M., ... Nurwati. (2013). Towards an Institutional Sustainable Agriculture in Parabela. World Applied sciences Journal 26 (Natural Resources and Development in Sulawesi, Indonesia), 55-59, 2013. https://doi.org/10.5829/idosi.wasj.2013. nrrdsi.26010

Nichols, J., Jones, K., Phillips, J. M., Newland, S. A., Roode, M., Mansfield, W., ... \& Cooke, A. (1995). Validated germline-competent embryonic stem cell lines from nonobese diabetic mice. Nature medicine, 15(7), 814-818.

Stainback, S., \& Stainback, W. (1988). Understanding \& Conducting Qualitative Research. Council for Exceptional Children, Publication Sales, 1920 Association Dr., Reston, VA.

Vermeji, J. (2000). The Formation of the Butoness Sultanate: Dutch Political Involvement in the Creation and Maintanance of Butonese Sultanate MA. Thesis Submitted at Australian National University. 
Wan Hashim Wan, T. (1997). Tamadum Melayu dan Pembinaan Tamadum Abad kedua Puluh satu. Dalam Ismail Hussein et, al. Tamadum Melayu Menyongsong Abad Kedua Puluh Satu. University of Kebangsaan Malaysia.

Yaacob, N. H., \& Maslan, A. (2014). Manusia dan perkembangan peradaban: beberapa aspek pemikiran Malek Bennabi dan Ali Syariati. Journal of Human Capital Development (JHCD), 7(1), 83-98.

Zahari, A. M. (1980). Darul Butuni. Sejarah dan Adatnya. Unpublish manuscripts.

Zuhdi, S. (1999). Labu Rope Wabu Wana. Sejarah Buton Abad XVII-XVIII. Disertasi Universitas Indonesia (in Indonesia).

\section{Copyrights}

Copyright for this article is retained by the author(s), with first publication rights granted to the journal.

This is an open-access article distributed under the terms and conditions of the Creative Commons Attribution license (http://creativecommons.org/licenses/by/3.0/). 